Tina llgo

\title{
Motivi norosti, brezbrižnosti in kanibalizma kot simboli družbene izprijenosti $v$ Lu Xunovih novelah
}

\begin{abstract}
Ključne besede: kitajska književnost, Lu Xun, motiv norosti, motiv brezbrižnosti, motiv kanibalizma, Dnevnik nekega norca, Resnična Zgodba o A Qju
\end{abstract}

\section{Uvod}

Lu Xun (1881-1936), ${ }^{1}$ eden največjih kitajskih pisateljev in oče moderne kitajske literature, je živel in ustvarjal na prehodu iz 19. v 20. stoletje. Rodil se je leta 1881, v času zatona mandžurske dinastije Qing (1644-1911), doživel njen propad in ustanovitev Republike Kitajske ter aktivno sodeloval pri kitajskem duhovnem preporodu, ki se je začel z literarno revolucijo leta 1917 in doživel vrhunec v času gibanja 4. maja 1919. Kot mladenič je odšel študirat na Japonsko, kjer se je seznanil z zahodno medicino in zahodnimi literarnimi deli. Leta 1906 se je odločil, da se bo posvetil izključno literarnemu ustvarjanju ter skušal prek literature osveščati ljudske množice. Lu Xun, katerega dela so sinonim za moderno kitajsko književnost, je bil novelist, esejist, pesnik, prevajalec, družbeni kritik, glavni pobudnik gibanja za uveljavitev kitajskega pogovornega jezika v šolstvu in literaturi, priznan predavatelj, ustanovitelj, urednik in sodelavec številnih literarnih revij ter vnet zagovornik korenitih družbenih sprememb, ki jih je bila Kitajska na prelomu stoletja, razpeta med tujim imperializmom in domačimi vojnimi mogotci, še kako potrebna. Predvsem pa je bil »bojevnik duha«, humanist in individualist, ki je hrepenel po duhovni in miselni svobodi (Ilgo, 2008, 389). Številnim mladim kitajskim pisateljem je pomagal na njihovi poti in jim bil za zgled. Kot razdvojeni intelektualec (Lyell, 1976, 304-313) se je že zelo zgodaj seznanil s tradicionalnim konfucijanskim družbenim in izobraževalnim sistemom, kasneje pa je kot študent medicine na Japonskem prejel tudi moderno izobrazbo. Bil je strokovnjak na področju kitajske kulture in literature, vendar je hkrati precej dobro poznal zahodno miselnost. Njegova razdvojenost mu ni prinesla zgolj prednosti, temveč tudi slabosti. Doživel je številna razočaranja in ustvarjalne krize ter bil nenehno razpet med dolžnostmi, ki mu jih je nalagala tradicija, in pogledi, ki jih je gojil kot moderni

1 Njegovo pravo ime je Zhou Zhangshou. V otroštvu, preden je nastopil formalno izobraževanje, se je preimenoval v Zhou Shurena (Tambling, 2007, 13-14). Takrat je spremenil tudi svoj vzdevek oziroma stilsko ime iz Zhou Yushan v Zhou Yucai. Psevdonim Lu Xun je prvič uporabil leta 1918, ko je izšla njegova prva novela Dnevnik nekega norca. Znan je tudi pod psevdonimom Ba Ren (Pollard, 2002, 70). 
intelektualec. Zato je bilo njegovo življenje, tako kot njegova prepričanja, polno protislovij. 30. maja 1925 je v pismu Xu Guangping² zapisal:

Težko jasno izrazim svoja stališča, ker so polna nasprotij. Če bi skušal razložiti, bi lahko dejal, da gre za nekakšno kolebanje med dvema poloma: humanizmom in individualizmom. Včasih ljubim ljudi, včasih jih sovražim. Kadar delam, včasih res delam za druge, včasih samo zato, da zabavam samega sebe, včasih pa garam do popolne izčrpanosti, ker upam, da bo življenje hitreje minilo. (Lu, 2000, 99)

$S$ pomočjo književnosti in umetnosti si je neprestano prizadeval podreti »zidove«, ki so Kitajsko ovirali na poti k modernizaciji. Njegove novele niso zgolj produkt trenutnega impulza, temveč predstavljajo skupek kreativnega mišljenja, pridobljenega $\mathrm{v}$ daljšem časovnem obdobju. Zaznamuje jih pomenska večplastnost, saj gre za zgodbo znotraj zgodbe, za dvojni princip, ki zahteva alegorično branje. Beremo jih lahko na več načinov, ki dopuščajo različne interpretacije. Prvi način je branje posamičnih novel kot realističnih pripovedi. Drugi način je branje, ki novel ne obravnava kot individualnih realističnih pripovedi, temveč kot medsebojno prepletene zgodbe, ki skupaj tvorijo nekakšen metapomen, razkrivajo pisateljevo avtobiografijo, njegovo osebno nezavedno, odkrivajo pomembno obdobje $\mathrm{v}$ kitajski zgodovini, pričajo o kitajskih navadah, običajih, vrednotah in normah ter oblikovanju ideje o kitajskem narodnem značaju, ki je deležen ostre kritike in postavljen pod drobnogled. Ta drugi način na eni strani vključuje zelo močan subjektivni ton, ki preveva tisto dimenzijo zgodb, ki razkrivajo Lu Xunova najgloblja čustva in občutke, njegove psihološke krize, dvome, njegovo nenehno razdvojenost med tradicijo in moderno, Vzhodom in Zahodom, brezbrižnostjo in "norostjo « ${ }^{3}$ ter aktivnostjo in pasivnostjo (političnim aktivizmom in umikom pred svetom, ki ustreza puščavniškemu umiku osamljenega posameznika); ${ }^{4}$ na drugi strani pa nam

2 Xu Guangping je bila Lu Xunova študentka na Visoki šoli za ženske v Pekingu in kasneje njegova življenjska sopotnica ter mati njunega edinega otroka Haiyinga. Sprva sta se spoznavala le prek pisem, ki so bila na začetku usmerjena predvsem k političnim in družbenim problemom na Kitajskem, izobraževanju in literaturi, postopoma pa so postala vse bolj osebna: začetni odnos profesor : študent se je prelevil v odnos dveh ljubimcev, ki sta nato nastopila skupno življenje (Pollard, 2002, 93-101 in 123-124).

3 Norost moramo v danem kontekstu razumeti kot genialnost, pronicljivost, ki Lu Xunovim protagonistom omogoča nenavadno jasen vpogled v družbeno realnost; omogoča jim spoznanje resnice, ki je drugim članom družbe, globoko integriranim v sistem in zaslepljenim, skrita.

4 Za veliko večino tradicionalnih kitajskih učenjakov uradnikov je značilna kulturno-politična opozicija med konfucijanstvom in daoizmom ali budizmom. Tradicionalni kitajski učenjaki, ki so se poleg uradniške službe na dvoru predajali tudi umetnosti (predvsem poeziji in slikarstvu), so bili pogosto nenehno razdvojeni med dolžnostmi, ki jim jih je nalagala državna uradniška služba, in svobodnim življenjem na podeželju, kjer so se v družbi svojih somišljenikov predajali pesnjenju in slikanju, daoizmu in budizmu. Primer tovrstnega učenjaka uradnika je Xie Lingyun, čigar "naklonjenost budizmu je tako kot njegova ljubezen do gora pomenila umik iz uradniškega sveta oziroma pred zahtevami dvora, s katerega politiko se ni strinjal (Lavrač, 1999, 125). Enako velja za znamenitega pesnika, slikarja in učenjaka iz tangovskega obdobja, Wang Weija (701-761), ki se je 
prek simbolike razkriva kitajsko kulturno in družbeno preteklost, ki je pomembno prispevala k oblikovanju Kitajske v Lu Xunovem času.

\section{Lu Xunov koncept »železne sobe«}

Kitajska se je na prehodu iz 19. v 20. stoletje znašla v nekakšnem družbenem, kulturnem in političnem vakuumu, ki ga avtor občuti kot »železno sobo « ${ }^{5}$ brez oken in vrat. Javno in zasebno je $\mathrm{v} \mathrm{Lu}$ Xunovih novelah medsebojno prepleteno in prežeto $\mathrm{z}$ enako travmo brezizhodnosti. Zasebna stiska izvira iz javne in je $\mathrm{z}$ njo tesno pogojena. Povprečnim množicam preživetje omogoča njihova nevednost, sposobnost prilagajanja, suženjska narava in brezbrižnost. Intelektualci se osmišljajo skozi politično in revolucionarno angažiranost, vendar na koncu vsi končajo kot prebujeni protagonisti $\mathrm{V} »$ železni sobi«. Da bi preživeli, se zavestno in namerno zatekajo k pozabi ali »norosti«.

Predpostavljajmo, da obstaja železna soba brez oken in vrat, soba, iz katere se je praktično nemogoče rešiti. Zdaj predvidevajmo, da so v tej sobi v večini ljudje, ki trdno spijo. Kmalu se bodo vsi zadušili. Ali drugače povedano, mirno bodo zdrsnili iz globokega spanca v pozabo, prizanesena jim bo tesnoba, ki bi jo občutili, če bi se zavedli neizbežnega pogubljenja. Recimo, da bi se pojavil ti in spustil ogromno raketo ter prebudil nekaj tistih, ki samo dremajo. V tem primeru bi šli v smrt, zavedajoč se vsega, kar jih čaka. Ali bi rekel, da si tem ljudem napravil uslugo? (Lu, 1956, 7) ${ }^{6}$

"Železna soba« je simbol za togo tradicionalno kitajsko kulturno in družbeno ureditev, ki omejuje ljudi do te mere, da se na koncu zatečejo k brezbrižnosti kot edinemu načinu, ki jim omogoča preživetje; ravnodušnost in pozaba jih rešita nenehnega trpljenja. Pa vendar ni samo to, saj vsebuje tudi bolj splošen in filozofski pomen. Glede na to, da je zgornji citat odziv na specifično zahtevo po pisanju, ${ }^{7}$ bi lahko rekli, da se $\mathrm{v}$ njem skriva neka namera. Avtorjevo pisanje se v tem primeru skorajda neizogibno prelevi v dejanje prebujenja. Gre za to, da bi spodbudil tistih nekaj individuumov, ki izstopajo iz povprečne množice in predstavljajo manjšino bistroumnih reformatorjev in revolucionarjev, katerih nekonvencionalni pogledi pogosto naletijo na odpor in nerazumevanje s strani nevednih množic. Znotraj ideološkega diskurza v času gibanja 4. maja se zdi ta razlaga zelo verjetna (Lee, 1987, 86-87). Metafora »železne sobe«

pred tegobami spletkarskega življenja na dvoru umikal na svoje posestvo v Lantianu ob reki Wang (Lavrač, 1999, 133), in številne druge.

5 Metaforo »železne sobe« je Lu Xun podal v predgovoru k zbirki novel Kriki (Lu, 1956, 7).

6 Vsi prevodi, pri katerih ni posebej naveden vir, so avtoričini.

7 Citat je namreč Lu Xunov odgovor na Qian Xiantongovo prošnjo, v kateri je ta izrazil željo, da bi Lu Xun prispeval novelo za njihovo novoustanovljeno revijo Nova mladina (Lu, 1956, 6-7). Qian Xuantong, kitajski lingvist, rojen v mestu Huzhou v provinci Zhejiang, je bil med drugim član uredniškega odbora revije Nova mladina (Lyell v: Lu, 1990, 26). 
opozarja na neprilagodljivost Kitajske svetovnim razmeram in njeno nesposobnost na področju transformacije družbenih, kulturnih in političnih razmer. Poleg tega, da predstavlja tradicionalno Kitajsko, ki je izolirana in odmaknjena od drugega sveta in katere togi konfucijanski družbeni sistem za ljudi ne pomeni nič drugega kot »železno sobo«, iz katere ni rešitve, hkrati predstavlja tudi temno in zamegljeno duševno stanje ljudi. V širšem smislu se torej nanaša na Kitajsko kot celoto, v ožjem smislu pa na vsakega posameznika, ki trdno »spi«, tj. posameznika, ki so ga življenjske izkušnje pripeljale do spoznanja, da je v okoreli tradicionalni družbi najlažji način preživetja zatekanje $\mathrm{k}$ brezbrižnosti in pozabi. Udejanjenje tega spoznanja človeka postopoma spremeni v apatičnega in družbeno ter politično neaktivnega, pokornega državljana, ki posredno omogoča obstoj statusa quo.

Pri analizi odlomka pozornost vzbudi predvsem ločnica, ki ljudi razdeli v tri kategorije, in sicer na »trdno speče množice«, ki se ne bodo nikoli prebudile, na »dremajoče«, ki bi se ob pomoči prebujenih morda lahko prebudili, in na »manjšino prebujenih «, ki so soočeni z veliko dilemo - ukrepati ali ohraniti status quo. Avtorju so bliže "prebujeni«, saj utelešajo njegove lastne izkušnje in občutke. Teh nekaj prebujenih individuumov njihovo prebujenje obvezuje $k$ temu, da skušajo zbuditi tiste, ki dremajo. Vendar pa so se kljub vztrajnemu prizadevanju na koncu primorani soočiti s porazom. Prebujeni tako postanejo »samotarji«, nezmožni prebuditi speče množice. Edino, kar jim ostane, je bolečina, ki jo občutijo, ko se zavedo bližajoče se neizogibne smrti (Lee, 1987, 87). Qian Xuantongova replika na Lu Xunov koncept »železne sobe« ponuja potencialno možnost rešitve: "Vendar če bi jih nekaj prebudil, ne moreš reči, da ne bi imeli nobenega upanja za rešitev iz železne sobe« (Lu, 1956, 7). Qianov odziv omili Lu Xunov pesimizem, saj avtor na koncu prizna, da nikakor ne more popolnoma ovreči upanja in na prijateljevo pobudo napiše prvo moderno kitajsko novelo, Dnevnik nekega norca (1918), ki naj bi predramila pasivne množice, hkrati pa naj bi bila v uteho nerazumljenim samotarjem.

Lu Xunove novele preveva nekakšno univerzalno sporočilo, ki presega kontekst Kitajske 20. stoletja. Osrednja ideja, ki ji avtor sledi skozi celotni novelistični opus, je, da kolektivno slepo zaupanje tradiciji ter preživelim vrednotam in normam onemogoča napredek in razvoj ter t. i. »norce« (genije, prebujene individualiste) sili k temu, da se odrečejo svojim pronicljivim spoznanjem in se prilagodijo večini. Lu Xun je v esejih večkrat opozoril, da je vse odvisno od človekovega položaja v družbi; plen se zlahka spremeni v plenilca in obratno, tako kot se potencialna žrtev »kanibalizma« zlahka preobrazi v »kanibala« in »ovca« v »pošast«. Vsak človek globoko v sebi skriva svoj »kanibalski jaz«, tako kot vsak lahko pooseblja »norca « ${ }^{8}$ ali brezbrižneža. Lu Xun, v širšem smislu, ne postavi pod drobnogled zgolj kitajskega narodnega značaja, temveč

$8 \quad$ V smislu genija. 
človeško naravo nasploh. Gledano iz te perspektive, Lu Xunove novele ne pomenijo zgolj kritike tradicionalnega kitajskega družbenega in političnega sistema, saj jih lahko označimo kot brezčasne.

\section{Dnevnik nekega norca kot kritika »kanibalske« človeške narave}

Z novelo Dnevnik nekega norca je Lu Xun razkrinkal tradicionalni kitajski družbeni sistem. Zgodba govori o mladeniču, ki zboli za preganjavico. Predstavlja si, da ga vsi ljudje hočejo požreti. Njegov brat ga zapre v sobo, kjer je pod stalnim nadzorom starejšega služabnika. Kadar koli mu dovolijo iti ven, ima občutek, da ljudje strmijo vanj in ga obrekujejo. Prepričan je, da so vsi vaščani, vključno z njegovim bratom, kanibali, ki kujejo zaroto proti njemu. Nenehno jih svari, naj se spremenijo. Svoje misli in vtise zapisuje v dnevnik. Pripovedovalec, njegov nekdanji sošolec, ga obišče, vendar naleti na brata, ki mu pove, da je »norec« že zdavnaj ozdravel in odšel v drugo provinco, kjer naj bi prevzel mesto v državni službi.

Novela je napisana v obliki dnevnika, v katerem avtor uporablja kitajski pogovorni jezik. Prvoosebna naracija mu omogoča izraziti pogled, ki je v ostrem nasprotju $\mathrm{z}$ javno in formalno sprejetim. Uvod v novelo je napisan v klasični kitajščini in služi kot kritika tradicionalnega kitajskega jezika. Tisto, kar naredi Lu Xunove novele tako skrivnostne in brezčasne, je t. i. simbolna naracija, ${ }^{9}$ kot je Leo Ou-fan Lee poimenoval narativno strukturo Lu Xunovih novel. Namerna opozicija med klasično (wenyan) in pogovorno kitajščino (baihua) namiguje na dejstvo, da je pogovorni jezik jezik prebujenih posameznikov. ${ }^{10}$ Zato se norec $\mathrm{v}$ dnevniškem zapisu izraža v pogovornem

9 S simbolno naracijo Lee označuje »narativno strukturo, znotraj katere »realistični« elementi v zgodbi dobijo pomen šele, ko jih povežemo z višjo, alegorično strukturo, ki jo je mogoče razbrati zgolj prek simbolov« (Lee, 1987, 65).

10 Obdobje prehoda iz dinastije Qing v Republiko kitajsko ter z njim tesno povezano gibanje za moderno kitajsko književnost, ki je dobilo polni zagon leta 1917, ko sta Chen Duxiu in Hushi objavila prve formalne predloge za literarno revolucijo, pomeni svojevrsten preobrat v kitajski družbeni, politični, zgodovinski, kulturološki in miselni stvarnosti. Na Kitajskem je bil to čas globoke družbene, politične in kulturne krize, ki so jo povzročili notranji politični konflikti, vse hujši pritisk tujih imperialnih sil ter naravne katastrofe, kar je pripeljalo do številnih uporov in vojn. Tedanje razmere so mlade kitajske izobražence spodbudile k ostremu obsojanju obstoječega sistema. Prepričani so bili, da sta tradicionalni pristop k izobraževanju ter klasični kitajski jezik predstavljala temeljni oviri v procesu modernizacije. Književnost, pisana v pogovornem jeziku, je sicer stoletja soobstajala s književnostjo, pisano v klasičnem jeziku, vendar so bila dela, napisana v pogovornem jeziku, izključena iz izobraževalnega sistema, ker so sodila v t. i. zabavno literaturo. Najvišjo pozicijo v hierarhiji literarnih zvrsti so zavzemali eseji in poezija, ki so ohranjali status quo, saj sta bili ti dve literarni zvrsti krojeni po meri doktrin in moralnih načel konfucijanskega nauka. Tako je bila širšim ljudskim množicam edini legitimni medij nerazumljiva klasična kitajščina. Literarna revolucija je pomenila konec »visoke« književnosti, pisane v klasičnem jeziku. Njeno mesto je zasedla ljudskim množicam razumljiva literatura, pisana $\mathrm{v}$ pogovornem jeziku, prej priznane eseje in tradicionalno kitajsko poezijo pa so zamenjali moderni kitajski romani, novele in družbenokritični eseji. V ospredje je prihajala tema osvoboditve posameznika iz okov preživelega sistema (Ilgo, 2008, 386-389). 
jeziku, medtem ko avtor za opis dialoga med pripovedovalcem zgodbe in norčevim bratom, ki je eden izmed »kanibalov« - tj. pripadnik družbe, ki podpira obstoječi družbeni in politični sistem -, uporabi klasični kitajski jezik. Največji odklon od tradicije predstavljata izredno subjektivni pogled in uporaba zahodnih literarnih modelov. V noveli Lu Xun izpostavi slabosti tradicionalnega kitajskega družinskega sistema, doktrine dostojnosti in kitajskega narodnega značaja ter napade tradicionalni kitajski družbeni sistem, ki ga označi kot »kanibalskega«. Če zgodbo beremo zgolj v kontekstu Kitajske 20. stoletja, jo lahko razumemo kot neposredno kritiko obstoječe družbe, katere vrednote in norme izvirajo iz konfucianizma. V širšem smislu pa je novela kritika človeške narave nasploh. Osrednje sporočilo novele je, da izprijenost obstoječega sistema »proizvaja kanibalizem in žre človečnost«. Motiv kanibalizma $\mathrm{v}$ simbolnem smislu se prepleta $\mathrm{z}$ dejanskimi primeri kanibalizma na Kitajskem, zagrešenega iz maščevanja in vraževernih prepričanj. Glavni protagonist novele pri prebiranju kitajske zgodovine med vrsticami razbere besede: Žreti ljudi! (Lu, 1956, 12) Lu Xun je bil prepričan, da Kitajska, prežeta s preživelim načinom mišljenja, ni bila nič drugega kot pojedina s človeškim mesom, na kateri ljudje nenehno žrejo drug drugega. Motiv kanibalizma je razumel kot izkoriščanje človeka po človeku, korupcijo, hipokrizijo ter človeško zahrbtnost in nepoštenost. Prepričan je bil, da se glavni problem Kitajske skriva v psihološkem stanju ljudi. Sklenil je, da v družbi primanjkuje odkritosti in poštenosti ter ljubezni in sočutja, morala in etika pa sta le besedi na papirju. V Dnevniku nekega norca protagonist prek svoje »norosti«, ki je v resnici čista razumnost, spregleda lažno konfucijansko naravo, ki se skriva za tančico navidezne kreposti in morale ter odkrije resnico: ljudožersko pojedino, na kateri močnejši žrejo šibkejše.

Gosta tema; ne vem, ali je dan ali noč. Pes družine Zhao je spet začel lajati.

Krutost leva, strahopetnost zajca, zvitost lisice ... (Lu, 1956, 14)

Lu Xun pričakuje, da bo šesti, najkrajši del dnevnika, pritegnil bralčevo pozornost. »Gosta tema« razkrije resnico o svetu, v katerem živi norec. To je svet, v katerem močni posamezniki z levjo krutostjo zatirajo šibke, medtem ko šibke žrtve plašno kot zajci klečeplazijo pred tistimi, ki posedujejo moč. Ob prvem srečanju se tako eni kot drugi vedejo zvito kot lisice, dokler ne postane jasno, kakšne položaje v družbi zavzemajo (Lyell, 1990, xxxviii). V Lu Xunovem eseju Nenadoma se mi je posvetilo beremo:

Obstajajo divje zveri v ovčji preobleki in ovce, preoblečene $\mathrm{v}$ divje zveri. Kajti te ovce so istočasno divje zveri. Kadar naletijo na zveri, bolj divje od njih samih, se vedejo kot ovce; kadar srečajo ovco, ki je šibkejša od njih, se obnašajo kot divje zveri. /.../ Še vedno se spominjam, kako uglajeno so po prvih demonstracijah 4. maja vojaki, ki so spominjali na neustrašno konjenico, ki naskakuje polje mladih poganjkov, s kopiti pušk pretepali 
neoborožene učitelje in študente, medtem ko so študentje preplašeno kričali in bežali kot ovce pred tigri ali volkovi. Vendar ali niso tudi študentje, ko so se zbrali, da bi napadli sovražnika, potolkli nekaj otrok, ki so jim bili v napoto? In ali niso v šoli pljuvali po sovražnikovih otrocih in jih prisilili, da so zbežali domov? Kaj ni to povsem v skladu z idejo tiranov o iztrebljanju celotnih klanov? /.../ Obžalovanja vredno je, da se Kitajci do ovac vedejo kot divje zveri, do divjih zveri pa kot ovce; zato naša država, tudi takrat ko se obnašamo kot zveri, izpade strahopetna. Če bo šlo tako naprej, je naša usoda zapečatena. (Lu, 2003a, 161-162)

Zaradi človeške dvoličnosti, ki prehaja iz ustrahovanja v klečeplazenje in obratno, smo ljudje istočasno ovce in zveri, plen in plenilci, žrtve in sleparji. Da bi Kitajska mogla izstopiti iz tega začaranega kroga, ji po Lu Xunovem mnenju ni treba razvijati nobenih novih kvalitet, temveč »bo dovolj, če bo mladina obrnila tradicionalno rabo teh dveh starodavnih atributov: Kadar je tvoj nasprotnik divja zver, se tudi ti obnašaj kot divja zver; kadar je ovca, se vedi kot ovca!« (Lu, 2003a, 162-163) V devetem delu Dnevnika nekega norca »norec« izrazi dvom, da bodo ljudje zmožni obvladati svojo dvoličnost in svoj »kanibalski značaj«.

Hočejo žreti druge in se hkrati bojijo, da bodo požrti. Zato s sumničavostjo v očeh nenehno opazujejo drug drugega.

Morali bi zgolj opustiti ta način mišljenja in bi lahko brez skrbi potovali naokoli, delali, jedli in spali. Pomislite, kako srečni bi bili! En sam korak bi morali narediti; prestopiti prag. In vendar se vsi ti očetje, sinovi, bratje, možje, žene, prijatelji, učitelji, učenci, sovražniki in celo ljudje, ki se ne poznajo med seboj, združujejo, da bi zadrževali drug drugega in se skušali pregovoriti, da to ni prava pot!

Raje bi umrli kot naredili ta majhen korak. (Lu, 1956, 16)

V Dnevniku nekega norca vaščani Lu Xunovega protagonista razglasijo za blaznega. S tem avtor namiguje na dejstvo, da si vsi posamezniki, ki se ne podredijo oblasti in se ne prilagodijo večini, delijo enako usodo - ljudje, ki jim želijo pomagati, jih ne razumejo ali jih celo preganjajo. V Lu Xunovem eseju To in ono (Povzdigovanje in zatiranje) beremo:

Kadar Kitajci naletijo na nekoga, ki jih spravlja v zadrego, uporabijo eno od dveh taktik, zatiranje ali poveličevanje. Kadar želijo koga zatreti, uporabijo stare družbene norme, moralo ali uradno oblast. Tako samotni bojevnik propade ravno zato, ker se bori za dobro množic; in šele takrat si drugi oddahnejo. Če jim ga ne uspe zatreti, ga povzdignejo; častijo in gostijo ga, dokler ni tako zadovoljen, da jim ne želi več hudega, in takrat lahko v miru počivajo. (Lu, 2003a, 222) 


\section{Luna kot simbol norosti in razsvetljenja: od upanja do obupa}

Lu Xunov »norec « pooseblja samotnega bojevnika, saj je zaradi izostrenega čuta za resnico družbeno marginaliziran in označen za blaznega. Na to namiguje ponavljajoči se element lune, ki ima številne simbolne pomene.

Nocoj prekrasno sije luna. Več kot trideset let je nisem videl. Danes sem jo zagledal. Počutim se popolnoma prerojenega. Šele zdaj razumem, da so bila zadnja tri desetletja ali več čista zabloda. Vendar moram biti nadvse previden. Zakaj bi me sicer Zhaov pes tako čudno gledal? Moj strah ni neutemeljen. (Lu, 1956, 9)

Po kitajski tradiciji luna simbolizira razsvetljenje, medtem ko na Zahodu pogosto simbolizira blaznost (gl. Lee, 1987, 54). Simbol lune je za vsa ljudstva sveta izrednega pomena. »... [Luna] je kozmičen simbol v vseh časih, od tistih, na katere ni spomina, do današnjih, in na vseh obzorjih." (Chevalier in Gheerbrant, 2006, 330) Številne interpretacije tega simbola se v podrobnostih sicer razlikujejo, vendar so si v izhodišču v glavnem zelo podobne. Luna oziroma mesec simbolizira žensko načelo, je simbol obnavljanja (lunine mene), transformacije, rojevanja, umiranja in ponovnega rojstva (cikličnosti) ter plodnosti. Astrologi lunarno cono osebnosti označujejo kot nočno, podzavestno cono naših nagonskih impulzov. Ta del človeške osebnosti je del prvobitnega, ki dremlje v nas in je še vedno živahno v spanju, sanjah, fantazmih in domišljiji (Chevalier in Gheerbrant, 2006, 331). Na Kitajskem je luna, tako kot pri večini ljudstev, ${ }^{11}$ povezana $\mathrm{z}$ ženskim principom, intuicijo, jasnovidnostjo in predirljivostjo. Polna luna simbolizira razsvetljenje, ozaveščanje nezavednega, medtem ko mlada luna pomeni nov začetek. Simbolna podoba meseca se pogosto pojavlja v klasični kitajski pesniški tradiciji. Maja Lavrač je simbol lune v Wang Weijevi (701-761) pesmi Bambusovje interpretirala takole:

Nadalje to občutenje povezanosti človeškega duha $\mathrm{z}$ naravo še stopnjuje simbolna podoba meseca, ki tu namiguje na pesnikovo duhovno razsvetljenje, trenutek čiste radosti in blaženosti, izkustvo najvišje sreče, ki se lahko "pripeti« potem, ko je pesnik določen čas meditiral v samoti in temi. Mesec oz. mesečina je ponoči namreč tisti svetlobni vir, ki razsvetljuje temačno praznino neba, tj. tisto temo, $v$ katero človeška zavest nikdar ne prodre in je ne more doumeti. (Lavrač, 1998, 169)

V Dnevniku nekega norca vaščani Lu Xunovega protagonista označijo kot blaznega (fengzi). Norec samega sebe v naslovu novele označi z drugim izrazom (kuangren), ki

11 Izjema so npr. Indijanci Gé iz osrednje in severovzhodne Brazilije, pri katerih je bila luna moško božanstvo in ni bila v nobeni sorodstveni zvezi s soncem (Chevalier in Gheerbrant, 2006, 329). 
ima sicer enak pomen, vendar v kontekstu novele $\mathrm{v}$ nasprotju z izrazom fengzi nosi bolj pozitivno konotacijo. Kuangren je torej povezan s pozitivno podobo norca/genija, medtem ko je fengzi povezan z negativno podobo blazneža/duševnega bolnika. Tisto, kar se zdi v očeh vaščanov/družbe blazno, je v resnici odraz genialnosti. V simbolu lune oziroma meseca, ki je ključni simbolni element novele Dnevnik nekega norca, sta združeni obe norčevi podobi. Avtor na ta način popolnoma zadovolji bralca, ki zgodbo razume zgolj kot realistično pripoved o nekom, ki zboli za preganjavico, in bralca, ki za popolnostjo opisa nekega mentalnega zloma odkriva simbolne pomene. Norec v prvem delu dnevnika pravi, da že več kot trideset let ni videl lune. Luna simbolizira resnico; norec si je trideset let zatiskal oči pred resnico in zdaj, ko jo je končno »ugledal«, se počuti prerojenega. Polna luna nam omogoča, da vidimo tudi $\mathrm{v}$ temi, in v tem primeru norcu omogoča, da kljub hierarhični mori, ki se skriva za masko konfucijanske morale, doživi razsvetljenje; končno spoznanje v zvezi z resnico o družbi in kulturi, ki ji pripada. V nadaljevanju nas Lu Xun prek simbola lune in kontrasta med svetlobo in temo popelje po »norčevem « in svojem lastnem notranjem potovanju od razsvetljenja do blaznosti, od svetlobe do teme, od upanja do obupa. Bolj ko se norec bliža resnici, bolj omejeno je njegovo gibanje. Starejši brat ga najprej zapre v študijsko sobo. Dovoljeni so mu zgolj občasni izhodi pod nadzorom starejšega služabnika. Ko skuša osvestiti »kanibale« o njihovem početju, brat pokliče zdravnika, ki ga razglasi za bolnega in mu odredi omejeno gibanje ter predvsem počivanje. Ko norec razkrinka celo lastnega brata, ga popolnoma osamijo. Njegovo razsvetljenje se spremeni v »železno sobo«. V drugem delu novele beremo: »Danes sploh ni meseca.« $(\mathrm{Lu}, 1956,10) \mathrm{V}$ tretjem delu se agonija zaostri: »Ponoči ne morem spati« (Lu, 1956, 10). V šestem delu novele svetlobo zamenja popolna tema: črna tema. "Ne vem, ali je dan ali noč.« ( $\mathrm{Lu}, 1956,14) \mathrm{V}$ enajstem delu je prebujeni posameznik popolnoma oropan glasu, svobode in upanja: "Sonce ne vzhaja in vrata se ne odpirajo; jesti mi dajo dvakrat dnevno« ( $\mathrm{Lu}, 1956,18)$. Norec po popolni osamitvi, kot izvemo v uvodu novele, ozdravi - postane »kanibal«. V »kanibalski« družbi imajo torej ljudje zgolj dve možnosti - postati ljudožerci ali njihove žrtve. V strogo hierarhično urejeni in medsebojno povezani kanibalski skupnosti je individualist obsojen na propad. "Ljudožerci« ga bodo najprej skušali preobraziti ali ga prisiliti k samouničenju. $\mathrm{V}$ primeru neuspeha ga bodo označili za zločinca, nevarnega za skupnost, in ga kot zvesti državljani obsodili na smrt. Zametke tovrstnega prepričanja najdemo že v Lu Xunovem eseju Moč demonske poezije (1908).

Ideal kitajske politike je: »Ne moti.« Cesar, ki je nameraval obdržati svoj prestol in postati oče neskončne linije veličanstev, je prepovedal motiti - zato je moral, ko se je pojavil genij, narediti vse, kar je bilo v njegovi moči, da ga je umoril /.../ Prelom mrtvila koristi vsemu človeštvu. Vendar to pomeni, da morajo vsi, od najvišjega boga do hlapčevega sužnja, spremeniti način 
življenja. Zato je morda povsem človeško, da se tisti, ki hočejo ohraniti stare navade, pridružijo morilcem, ki bodo poeta zadušili že v zibelki. (Lu, 1956, 199-200)

\section{Kitajski kolektivizem in brezbrižnost množic}

Glavna značilnost Lu Xunovih prebujenih posameznikov je, da so sami v sovražnem svetu. Kitajski kolektivizem, pred ali po padcu zadnje dinastije, ni dopuščal individualizma. V času študija na Japonskem je bil Lu Xun trdno prepričan, da Kitajska lahko stopi na pot napredka le skozi osvoboditev posameznika.

Če hočemo doseči nivo razumne politike, moramo proučiti preteklost in se pripraviti na sedanjost, opustiti materialno in povzdigniti duhovno, se zanašati na individuuma in ne na mase. Ko bo individuumu omogočeno, da izkoristi vse svoje kapacitete, bo država pridobila moč in se povzdignila. ( $\mathrm{Lu}$ v: Lee, 1987, 21)

Glavne ovire ne predstavlja pomanjkanje volje pri t. i. »norcih«, temveč apatičnost in brezbrižnost celotne družbe. Prebujeni posamezniki, ki čutijo potrebo po tem, da bi rešili druge, izgubijo upanje, ker spoznajo, da ni nikogar več, ki bi ga lahko rešili; nihče ne želi biti rešen in nihče se ne zaveda, da ljudje potrebujejo odrešenje. Lu Xun je bil prepričan, da sta brezbrižnost in nepripravljenost soočiti se $\mathrm{z}$ realnostjo glavni značajski pomanjkljivosti kitajskega naroda, ki povzročata zaton najpomembnejših vrednot (sočutja in odkritosti) in preprečujeta družbeni, politični in kulturni napredek. Po mnenju Lin Yutanga sta ti dve značilnosti zavestni produkt kitajske kulture, značilni za tradicionalni način mišljenja, ki ga pogojujejo specifične družbene razmere. V deželi, kjer je bila individualnost strogo obsojana, je indiferentnost postala usodno pomenljiva za vsakogar, ki je hrepenel po razmeroma mirnem življenju. V okoreli tradicionalni in strogo hierarhični družbi je ljudem omogočala preživetje. Razvila se je zaradi odsotnosti pravne zaščite in je predstavljala neke vrste samozaščito (Lin, 2002, 48-49). Ideja o begu pred resničnostjo je v Dnevniku nekega norca zelo jasno izražena v dialogu med »norcem « in neimenovanim mladeničem. »Norec« skuša ugotoviti, ali se mladenič zaveda »kanibalske« človeške narave. Kljub dejstvu, da »kanibalizem» prežema vse pore družbe, si tega nihče ne upa priznati, ker »kanibalom« življenje v moralno oporečni družbi povsem ustreza. Za kakršen koli napredek, ki bi vodil v boljšo prihodnost, bi bilo treba spremeniti celotno družbeno strukturo.

Po vsem tem bi celo oni morali razumeti, kaj se resnično dogaja ...

Nenadoma je nekdo vstopil. Bilo mu je kakšnih dvajset let. Njegovih potez nisem mogel natanko razločiti. Usta so se mu razvlekla $\mathrm{v}$ nasmeh, ko mi je prikimal. Njegov nasmeh se mi je zdel narejen. Nato sem ga vprašal: »Je 
ljudožerstvo dobra stvar? «Še vedno smehljajoč se je odgovoril: »Kdo bi hotel žreti ljudi, če ni lakote? « Takoj sem spoznal, da je eden izmed njih - ena izmed pošasti, ki žrejo ljudi. Moj pogum se je postoteril in vprašal sem ga: »Je to dobro?«

"Zakaj sploh načenjaš pogovor o tem? Šaljivec si, kajne ... Danes je res čudovito vreme."

»Vreme je res čudovito. Tudi luna jasno sije, vendar mene še vedno zanima, ali je to dobro."

Omahoval je, nato pa negotovo zamrmral: »Ne ...»

»Ni dobro? Zakaj pa potem še vedno žrejo ljudi?«

"Nihče nikogar ne žre ...»

»Nihče nikogar ne žre? V Volčji vasi celo v tem trenutku žrejo ljudi. Poleg tega je v vseh knjigah s svežo krvjo zapisano prav to! « Njegov obraz je postal mračen kot lito železo. Zagledal se je vame in rekel: »Morda res, ampak saj je že od nekdaj tako ..."

»Ali je potem to dobro samo zato, ker je že od nekdaj tako?«

"Nočem razpravljati s tabo o tem. Če vztrajaš pri tem pogovoru, si ti tisti, ki je v zmoti!« (Lu, 1956, 15-16)

Iz odlomka je razvidno, da je motiv kanibalizma v noveli metafora za izprijeno človeško naravo. Lu Xunov norec živi v svetu, polnem neozdravljivih »ljudožercev«. Njegova sposobnost kritične presoje ga ne obvaruje pred kanibalsko množico, temveč zgolj zaostri in poglobi njegovo agonijo. Norec na koncu spozna, da je verjetno tudi sam žrl druge in bo prej ali slej požrt.

Nimam več moči, da bi razmišljal. Šele danes sem spoznal, da živim v svetu, kjer že štiri tisoč let žrejo ljudi. Ko je sestrica umrla, je brat postal gospodar hiše, in kdo ve, ali nas ni na skrivaj hranil z njenim mesom. Morda sem nevede pojedel več kosov sestrinega mesa, zdaj pa je prišla vrsta name ... (Lu, $1956,19)$

Kot izvemo od protagonistovega starejšega brata $\mathrm{v}$ predgovoru $\mathrm{k}$ norčevemu dnevniku, ki uokviri zgodbo znotraj zgodbe, je norec naposled »ozdravel« in se zaposlil kot uradnik. Genij je bil torej uspešno prevzgojen in vključen v kanibalsko družbo. Lu Xun na glavne hibe kitajskega narodnega značaja ni opozarjal zgolj v novelah, temveč tudi v esejih.

Ker se Kitajci bojijo soočanja $\mathrm{z}$ dejstvi, se zatekajo k prikrivanju in prevari, da bi iznašli premetene metode umika. To se jim zdi povsem normalno in primerno, kar kaže na strahopetnost, lenobo in podle zvijače, značilne za naš narodni značaj. Sprijaznjeni s tem, da smo iz dneva v dan bliže propadu, si domišljamo, da napredujemo od slave do slave. (Lu, 2003a, 202) 


\section{A Qjeve »duhovne zmage« kot sredstvo za beg pred resničnostjo}

Zgornja misel je idealen uvod v Lu Xunovo najdaljšo in najznamenitejšo novelo, Resnično zgodbo o A Qju, ki je bila prvič objavljena v nadaljevanjih med decembrom 1921 in februarjem 1922 pod psevdonimom Ba Ren, in sicer v literarni prilogi Pekinškega dnevnika. Zgodba je razdeljena na devet poglavij, med katerimi prvo poglavje predstavlja nekakšen uvod v novelo; ostalih osem poglavij je napisanih v obliki življenjepisa glavnega protagonista. Kot so izpostavili številni literarni kritiki, Lu Xun v noveli graja tradicionalni kitajski družbeni sistem, ki temelji na konfucianizmu, namišljeno kitajsko superiornost in revolucijo 1911. Splošno znano je, da avtor skozi A Qjevo biografijo razkriva tipične značilnosti povprečnega Kitajca. Vendar si ne moremo kaj, da ob branju ne bi pomislili, da se A Qjeve značajske lastnosti ne nanašajo zgolj na Kitajce. A Q trpi za popolnim pomanjkanjem samozavedanja. Ne ve nič o svoji preteklosti in sedanjosti ter ne more načrtovati prihodnosti; ne pozna niti svojega pravega imena. V zgodbi ni natančnega opisa njegove zunanjosti (razen garij na njegovi glavi). ${ }^{12}$ Protagonist je duševno in telesno prazen in se ravna zgolj po instinktu: ne razmišlja, ne ljubi ali sovraži, temveč stremi $\mathrm{k}$ zadovoljevanju osnovnih potreb po hrani, zavetju in spolnosti (McDougall in Louie, 1997, 97). Je brezdomec, ki živi v vaškem templju, priložnostni delavec brez zemlje in materialnih sredstev. Kljub temu, da ga ljudje nenehno izkoriščajo, se mu posmehujejo in ga ponižujejo, je A Q prepričan v svojo »duhovno zmago«. Pogosto se spravlja na šibkejše ter prezira tako vaščane kot meščane. Vsemu navkljub pa ima A Q »o sebi kar najboljše mnenje« (Lu, 2008, 100). Njegova samoprevara (duhovne zmage) simbolizira odnos med Kitajsko in zahodnimi velesilami ter Japonsko. Četudi je Kitajska nenehno poudarjala lastno kulturno superiornost, so jo zahodne sile vedno znova porazile, dokler ni končno postala polkolonialna država. Reforme, h katerim se je zatekala, so bile večinoma površinske, tako kot revolucija 1911, ki razen sprememb nazivov in pričesk ${ }^{13}$ ni prinesla nobenega konkretnega družbenega in političnega napredka. Za mnoge luxunologe A Q predstavlja simbol nenehno ponižane in poražene Kitajske.

Preden so ga izpustili, so morali iz navade z njegovo glavo še nekajkrat udariti ob nekaj trdega, kar koli se je pač našlo v bližini. Šele potem so zadovoljno odšli, prepričani, da tokrat niso samo zagotovo zmagali, temveč so A Qja tudi dokončno uničili. A že čez nekaj sekund se je tudi on sam pobral in prav tako zmagoslavno zapustil prizorišče. Najprej je pomislil na to, da je prvovrstni

12 Garje na A Qjevi glavi simbolizirajo bolno stanje Kitajske, podobno kot različne telesne pohabljenosti ter druge psihične in fizične bolezni v Lu Xunovih novelah (Vuilleumier, 2010, 1).

13 Kitajci so opustili mandžurske kite, ki so jih morali v času dinastije Qing nositi v znak ponižanja. 
zaničevalec samega sebe na svetu. Potem je frazo "zaničevalec samega sebe« kratko malo pozabil in to, kar je ostalo, je bilo »prvovrstni«. Ta izraz je bil sicer rezerviran samo za izjemno genialne učenjake, ki se pri državnih uradniških izpitih najbolje odrežejo. »No, vidiš, kaj pomeniš, « je zadovoljno zamrmral predse. (Lu, 2008, 102-103)

Že sam vzdevek »A $\mathrm{Q}$ « namiguje na protagonistov značaj in posredno na značilnosti kitajskega naroda, kot jih je videl Lu Xun. Pismenka, ki se izgovori kot »A«, je na Kitajskem, še posebno na jugu, splošna predpona za imena. Vizualna podoba črke »Q« spominja na brezobličen obraz z mandžursko kito ali t. i. prašičjim repom, ${ }^{14}$ etimološko pa se nanaša na pismenko "gui«, ki ima v kitajskem jeziku naslednje pomene: 1 . lovor, lovorike, slava, zmaga, 2. dragocen, visoko cenjen, vreden/ plemenit, veličasten, 3. duh, prikazen, demon. Medtem ko je A Q vedno prepričan $\mathrm{v}$ svojo duhovno zmago, se visoko ceni in se ima za potomca plemičev, je $\mathrm{v}$ resnici zgolj prikazen, simbol živega mrtveca. Je tipični predstavnik družbe, ki se ne zaveda svoje »ljudožerske narave«. Na koncu zaradi nevednosti postane žrtev sistema, ki ga je ustvaril. A Q je človek, ki je popolnoma neseznanjen s kitajskimi političnimi in družbenimi razmerami, vendar kljub temu želi aktivno sodelovati v protirevoluciji ali revoluciji. Ker je neveden in o ničemer nima prav trdnega mnenja, razen morda o tem, da morajo biti ženske pokorne moškim, se zlahka »obrača po vetru«.

\section{Spektakel obglavljenja kot simbol brezbrižnosti in razčlovečenja}

Potem ko A Q nekaj časa preživi v mestu, ob vrnitvi v Weizhuang vaščanom v zanosu pripoveduje o dogodkih, ki jim je bil priča. Višek njegovih izkušenj je opazovanje spektakla obglavljenja sonarodnjaka.

"No, in je kdo od vas že kdaj koli videl pravo pravcato obglavljenje?« je vprašal A Q in nadaljeval: „Hm, to je resnično lep pogled. Obglavljenje revolucionarjev je resnično zanimivo.« /.../ „Ššššiiiiicccc! ... In že je mrtev!« Bradati Wang se je grozno prestrašil in koj potegnil glavo nazaj med ramena. Ostale poslušalce je preplavil val prijetnega drgetanja. Še nekaj dni po tem je bradati Wang stopal naokoli, kot bi bil tistega dne resnično obglavljen. Sploh si ni več upal v A Qjevo bližino. Tudi ostali vaščani so se počutili podobno. Seveda ne bi mogli trditi, da je A Qjev novi sloves presegel sloves, ki ga je užival prečastiti Zhao, a brez pretiravanja lahko rečemo, da sta bila v očeh vaščanov oba moža poslej približno enakovredna. (Lu, 2008, 126-127)

14 V času mandžurske dinastije Qing so morali Kitajci v znak ponižanja nositi kite, ki so jih imenovali tudi »prašičji repki«. 
Obglavljenje v Lu Xunovih novelah simbolizira smrt duhà tistega, ki je obglavljen, tj. upornika, revolucionarja, prebujenega posameznika, ki pomeni grožnjo za obstoječi sistem. Hkrati simbolizira smrt Kitajske v duhovnem smislu in razčlovečenje Kitajcev, kajti brez sedeža duhà so ljudje poživinjeni - odvzeta jim je sposobnost razmišljanja in kritične presoje. S simbolom obglavljenja se najprej srečamo v predgovoru k zbirki novel Kriki, kjer Lu Xun opiše dogodek, ki naj bi botroval njegovi odločitvi za opustitev študija medicine v prid literarnemu ustvarjanju. Lu Xun je ob pogledu na diapozitiv, ki je prikazoval kitajskega ujetnika v rokah japonskih vojakov, prišel do spoznanja, da so Kitajci razčlovečeni. Kazen za obtoženčevo domnevno vohunjenje za Ruse je bila obglavljenje. Avtorja je osupnila brezbrižnost množice kitajskih opazovalcev, ki so se zbrali okoli obsojenega, da bi opazovali spektakel.

Poneumljeni in šibki ljudje, pa naj bodo fizično še tako močni in zdravi, bi lahko služili le kot žrtve ali kot priče takih nesmiselnih spektaklov. Če je tako, se ni treba vznemirjati s tem, koliko jih bo zbolelo in umrlo. Prva in najpomembnejša naloga je spremeniti njihovega duha. $(\mathrm{Lu}, 1956,5)$

Téma, ki zadeva brezbrižne, apatične, vendar spektakla željne »kanibalske» množice, je prisotna $\mathrm{v}$ več novelah, četudi ni nujno vedno povezana $\mathrm{z}$ dejanjem obglavljenja v dejanskem smislu. Moderna Kitajska je v simbolnem smislu obglavljena; nevedne, neizobražene in spektakla željne množice so živi mrliči, potencialne žrtve, ki se ne zavedajo bližajoče se smrti. Večtisočletna prisotnost »kanibalizma« je ljudi razčlovečila do te mere, da obglavljenje zanje ni več zločin, temveč karneval. V eseju Kaj se zgodi, ko Nora zapusti dom? (1923), Lu Xun na kratko povzame glavne značilnosti množic, ki se odražajo skozi takšne ali drugačne vedenjske vzorce posameznikov ali kolektiva v njegovih novelah.

Ljudske množice, še posebej na Kitajskem, so vedno gledalci drame. Če se žrtev na odru obnaša junaško, gledajo tragedijo; če trepeta in drhti, gledajo komedijo. Pred trgovino z bravino v Pekingu se pogosto zbere nekaj ljudi, ki z očitnim naslajanjem zijajo v odiranje ovce. In to je vse, kar imajo od tega, če se človek žrtvuje. Povrh vsega, ko se le nekaj korakov oddaljijo od prizorišča, nemudoma pozabijo tudi na to trohico užitka. S takšnimi ljudmi ne moreš prav nič; rešiš jih lahko le tako, da jim ne omogočiš gledati drame. (Lu, 2003a, 91-92)

Žrtev obglavljenja ali usmrtitve je pri Lu Xunu nujno »norec«, izobčenec, osamljeni posameznik, ki je kaznovan bodisi zato, ker izraža nestrinjanje z obstoječim sistemom in statusom quo (revolucionarja Xu Xilin in Xia $\mathrm{Yu}$ ), bodisi zato, ker sistem potrebuje grešnega kozla (A Q), da bi na ta način okrepil svojo avtoriteto in posvaril ljudstvo pred "nevarnostjo« svobodnega razmišljanja in delovanja. V prvem primeru je žrtev tista, ki je prebujena in skuša prebuditi speče množice. Obtoženec in množice, ki so obtoženčevi 
sonarodnjaki in potencialne žrtve, so del istega »telesa«. V ljudskih množicah bi moralo obglavljenje prebuditi sočutje do sonarodnjaka in jih spodbuditi k boju proti hipokriziji, korupciji, represiji, spodbujanju kolektivizma in zatiranju individualizma ter avtokratskemu sistemu, vladi in posameznikom, ki povečujejo svojo moč na račun zatiranja nevednih in šibkih pripadnikov ljudskih množic. A ker so kitajske množice zaradi travmatičnih izkušenj bližnje preteklosti (opijske vojne, upor Taipingov, kitajskojaponska vojna, boksarska vstaja itd.), ki so se globoko zasidrale v njihovo podzavest, v simbolnem smislu že doživele obglavljenje, jim ostane le še telo, oropano uma. Redki prebujeni posamezniki se tako nujno zaman žrtvujejo za »speče« množice.

\section{A Q: grešni kozel na »kanibalskem banketu«}

A Qjev ugled v vasi zaradi njegove prisotnosti na spektaklu obglavljenja v mestu močno zraste. $\mathrm{V}$ sedmem poglavju novele govorice o revoluciji dosežejo Weizhuang in A Q je sprva precej zmeden. Ker je po naravi konformist, ni nikoli preveč maral revolucionarjev in je nanje gledal kot na ljudi, ki povzročajo težave. Vendar ko odkrije, da se pripadniki elite, nosilci moči v vasi, nadvse bojijo revolucionarjev, mu ti prirasejo $\mathrm{k} \mathrm{srcu}$.

Sam pri sebi je pomislil: »Tale revolucija sploh ni tako napak! Bo vsaj pokončala vse te nagnusne lumpe! Fuj, kako so zoprni! Še sam se bom pridružil revolucionarjem!«/.../ Še sam ni vedel zakaj, a kar naenkrat ga je preplavil občutek, da je sam revolucionar in da so vsi vaščani Weizhuanga njegovi ujetniki. To ga je navdalo z vzneseno radostjo, tako da se ni mogel več zadržati in je pričel glasno vpiti: »Upor! Upor!« (Lu, 2008, 132-133)

Zgornji odlomek spominja na Lu Xunov primer družbene ureditve Kitajske, ki deluje po principu lev-zajec-lisica oziroma ovca-zver (Lu, 1956, 14). Takoj ko zatiranemu daš moč ali zgolj občutek moči, se bo iz plašnega zajca preobrazil v krutega leva. A Q se kot revolucionar spravi na najbolj nebogljene - nune v samostanu Mir in očiščenje. Ob prihodu na kraj ves osupel ugotovi, da sta sinova plemiških družin Zhao in Qian že uresničila njegov namen: uničila sta cesarski napis, simbol Mandžurcev, ukradla antično kadilo in pretepla staro nuno. A Q se domisli, da se mora pridružiti skupini, zato poišče revolucionarje. Izkaže se, da so to pripadniki obstoječe elite, ki A Qja niti po pomoti ne želijo imeti v svojih vrstah in ga grobo naženejo. Kljub dejstvu, da obstoječi sistem $\mathrm{v}$ svoji novi revolucionarni preobleki ostane nespremenjen, A $\mathrm{Q}$ še vedno upa, da se bodo od nekod prikazale prave revolucionarne čete $\mathrm{z}$ belimi čeladami in orožjem. Neke noči, ko se rahlo vinjen pozno vrača iz krčme, ga privabi hrup. Odkrije skupino vojakov v belih čeladah, ki ropajo hišo gospoda Zhaoja. Nekaj časa jih opazuje, nato pa se, besen, ker ga niso povabili zraven, vrne v tempelj in utone 
v globok spanec. Čez nekaj dni A Qja aretirajo za rop, ki ga ni zagrešil. Prisiljen je podpisati priznanje. Šele ko ga odvlečejo iz zapora, da bi ga na ulicah izpostavili kot javni zgled, se mu posveti, da bo usmrčen. Sprva ga misel na smrt pretrese, vendar se takoj za tem zopet zateče k duhovni zmagi. Bližajo se morišču in A Q se skuša spomniti kakšnega izzivalnega odlomka iz opere, ki bi ga lahko zapel. ${ }^{15} \mathrm{~V}$ kriku spravi iz sebe le del junaške fraze, ki jo po tradiciji recitirajo obsojeni. Spektakla željne množice se ob njegovem vzkliku razživijo. Njihovo kričanje, ki spominja na tuljenje požrešnih volkov, končno prebije A Qjev obrambni zid in ga sooči s kruto realnostjo.

»Bravo, « so začeli vzklikati ljudje, kot bi zatulili volkovi. /.../ A Q je s pogledom ponovno objel množico, ki ga je obkrožala. Kar naenkrat so mu vročično prenapeti možgani v duhu pričarali podobo iz preteklosti. Volčje tuljenje množice ga je spomnilo na sestradanega volka, ki ga je srečal pred štirimi leti na vznožju hriba. Ta volk mu je vztrajno sledil v varni razdalji in ves čas cedil sline po njegovem mesu. A Qja je bilo na smrt strah, a na srečo je imel s seboj sekiro, $s$ katero bi se lahko ubranil pred morebitnim napadom. Tako se je živ in zdrav vrnil v Weizhuang. A nikoli ne bo pozabil oči tega volka. Bile so krute, a hkrati prestrašene, lesketale so se kot dve hudičevi iskri, ki sta iz daljave prebadali njegovo kožo in se mu zarivali v meso. Sedaj pa so vanj zrle popolnoma drugačne, še mnogo krutejše oči. Te oči, oči množice, so bile kalne in motne, in vendar se je zdelo, kot bi tlele od nekakšnega notranjega pohlepa. Njegov junaški recital so posrkale vase, zdaj pa so čakale, kaj jim bo še ponudil, kaj užitnega jim še lahko da razen svojega mesa in svoje kože. Te oči so mu neprestano sledile, ne preblizu in ne predaleč.

Zazdelo se mu je, kot bi se vse te oči zlile v en sam prediren pogled, ki ga je prebadal in srkal vase njegovo dušo.

»Na pomoč!»"

Toda A Q teh besed sploh ni izgovoril. Spet se mu je stemnilo pred očmi, v ušesih mu je zabrnelo in že se je njegovo telo lahkotno sesulo v drobcen prah. (Lu, 2008, 149-150)

Kanibalski pogledi množice pričajo o nezmožnosti sočutja do sovaščana, sonarodnjaka in ljudi nasploh. Volčje oči simbolizirajo čredni nagon množic; te so podlegle ideologiji, ki gradi svojo moč na podrejanju individuuma kolektivu. Po kitajski tradiciji volk simbolizira krutost, požrešnost in grabežljivost. Kitajski pregovor se glasi: »Bolje ubiti deset tigrov kot enega samega volka, kajti tigri so samotarji, medtem ko volkovi lovijo v krdelu in se maščujejo za vsakega umorjenega člana« (Eberhard, 1983, 316). Nevedni, brezoblični A Q torej postane grešni kozel, javni zgled, žrtev sistema. Tik pred smrtjo doživi hipno spoznanje o zablodi, ki se ji je predajal celo življenje:

15 Na smrt obsojeni so pred usmrtitvijo običajno glasno peli odlomke iz popularnih oper ali junaške pesmi, s čimer so kazali svoj pogum (gl. Lyell v: Lu, 1990, 170). 
duhovne zmage, ki so mu omogočale preživeti v »kanibalskem svetu«, so lažne; smrt je neizbežna. Po eni strani se zdi, da je A Q tipični predstavnik brezbrižnih in nevednih množic, po drugi strani pa ne moremo mimo dejstva, da ga množice zavračajo in da je v resnici samotar. A Q se je v vsakem trenutku in v vsakršni situaciji sposoben odtujiti od realnosti. Njegova sposobnost spreminjanja poraza $\mathrm{v}$ zmago in ohranjanja samozavesti ter njegova neverjetna zmožnost pozabljanja namigujejo, da beži pred nečim; najverjetneje pred travmatičnimi izkušnjami iz preteklosti in pred samim seboj. Je produkt represivnega družbenega in političnega sistema, ki ljudi sčasoma spremeni v indiferentne, nevedne državljane, hkrati pa je tudi simbol Kitajske, ki zaradi apatičnosti povprečnih množic in celo nekaterih intelektualcev nazaduje in počasi umira, dokler ni končno ob glasnem vzklikanju lastnih državljanov usmrčena. A Q šele tik pred smrtjo prestopi prag brezbrižnosti in začuti trpljenje. Lu Xun je 22. marca 1925 v pismu Xu Guangping zapisal:

Čim človek preseže stanje brezbrižnosti, se njegovo trpljenje poveča; glede tega se ne da nič storiti. Tisto, čemur pravimo "upanje za prihodnost«, je zgolj nekakšna oblika samotolažbe - ali preprosto samoprevara - in enako je s tistim, čemur pravimo "prepuščanje sedanjosti«. Če se nekdo želi na Kitajskem prilagoditi času in okolju, mora biti tako otopel, da ni sposoben misliti na "prihodnost« in ne ve nič o »sedanjosti«, vendar ko nekdo pridobi nekaj znanja, ni več poti nazaj. (Lu, 2000, 35)

\section{Sklep}

Lu Xunove novele so na eni ravni tesno povezane s časom, v katerem je ustvarjal, vendar so, ker je javno in zasebno $\mathrm{v}$ njih prepleteno, hkrati tudi izraz avtorjevih lastnih čustev, občutkov, prepričanj in frustracij. Ta izrazito subjektivni pogled razmišljujočega ustvarjalca in premišljena uporaba simbolnih elementov jim omogoča presegati prostor in čas. Lu Xun je bil kot razdvojeni intelektualec nenehno razpet med tradicijo in moderno, Vzhodom in Zahodom ter "norostjo « in brezbrižnostjo. Kljub dejstvu, da je bil moderno usmerjen, je materi na ljubo izpolnil vse dolžnosti, ki mu jih je nalagala tradicija. Po smrti očeta je postal glava družine; na materino pobudo se je vdal dogovorjeni poroki in se poročil z Zhu An, ki je ni nikoli ljubil, ter se je rad pošalil, da je bolj materina žena kot njegova (Pollard, 2002, 66). V času velikega razočaranja, ki ga je doživel po ustanovitvi Republike Kitajske leta 1911, se je za nekaj let umaknil v samoto ter proučeval stare kitajske tekste in zgodovino; kot je sam zapisal, je skušal pozabiti in otopeti. Vse do leta 1918, ko je izšla novela Dnevnik nekega norca, ni napisal nobenega leposlovnega dela. Literarna revolucija in gibanje 4 . maja sta ga zopet zalučala v središče družbenega dogajanja, v katerem se, vse dokler ni spoznal svoje bodoče življenjske sopotnice, študentke Xu Guangping, ni želel politično 
izpostavljati. Lu Xun je v novelah Dnevnik nekega norca in Resnična zgodba o A Qju na izredno prefinjen način, ki zahteva alegorično branje, obudil dva (na prvi pogled različna) protagonista - prebujenega norca in spečega A Qja -, ki se vsak na svoj način spopadata s svetom okorelosti, praznoverja, krutosti in hipokrizije. "Norec«, ki je presegel otopelost, se na vso moč trudi prebuditi speče množice, katerih predstavnik je A Q, ki se nenehno zateka k pozabi in brezbrižnosti kot najučinkovitejšima sredstvoma za skrajno zmanjšanje trpljenja. Njegovo popolno pomanjkanje samozavedanja, njegova mentalna in moralna praznost ter samoprevare so posledica družbeno in politično okorelega sistema, ki zatira individualizem in spodbuja kolektivizem $\mathrm{v}$ smislu dobro nadzorovane in poslušne črede ovac, katerih čuti so otopeli do te mere, da slepo sledijo »gospodarju«. Lu Xun, razočaran nad tedanjo družbeno in politično situacijo na Kitajskem, je nekoč zapisal:

Čutim, da mi je končno zmanjkalo besed. ... Ne vem, kaj nas čaka. Bojim se, da nič dobrega. Vendar se še vedno skušam rešiti na svoj stari način: najprej z otopelostjo in nato s pozabo. (Lu v: Lee, 1987, 123)

Norec in A Q ne poosebljata dveh ločenih individuumov, temveč dve različni osebnosti ali identiteti znotraj enega posameznika, ki prehajata druga $\mathrm{v}$ drugo, glede na okoliščine, v katerih se človek znajde. Če je norec »bojevnik duha«, potem je A Q tisto, kar od njega ostane po številnih brezplodnih bojih.

Moj namen je, da bralec ni sposoben izraziti, kdo bi ta literarni lik lahko bil, razen njega samega, tako da se ne more umakniti in postati opazovalec, temveč je prisiljen domnevati, da je to njegov portret, če ne portret vsakega človeka, kar ga bo morda spodbudilo k razmišljanju. (Lu, 2003b, 141)

Lu Xun je prav tako nenehno kolebal med A Qjem in »norcem«; skušal je pozabiti, vendar so ga duhovi preteklosti vztrajno zasledovali, čutil je, da ga občutek brezizhodnosti vodi $\mathrm{k}$ »norosti«, vendar ni nikoli popolnoma izgubil nadzora nad samim seboj. V pismu je Xu Guangping posvaril, naj se ne spremeni v norca/norico, kajti ko se nekomu zmeša, morda to zanj ne pomeni nič posebnega, za druge pa pomeni konec sveta (Lu, 2000, 110). »Zato, « pravi Lu Xun, »si nikoli ne bom dovolil, da bi znorel.« (prav tam) Simbolika, ki se skriva za motivi kanibalizma, brezbrižnosti in norosti, je večna in močno aktualna tudi danes. Veličina Lu Xunovih del je v tem, da ponujajo podroben in pronicljiv vpogled $\mathrm{v}$ kitajsko stvarnost 19. in 20. stoletja in so hkrati brezčasna. Bralec lahko danes, enako kot v času nastanka novel, v Lu Xunovih protagonistih prepozna sebe. Zgodbe lahko $\mathrm{v}$ najožjem smislu razume kot zrcalo nekega zgodovinskega obdobja, $v$ širšem pa kot odsev družbe, v kateri živi, in njenega vpliva na ljudi. 


\section{Literatura}

Chevalier, Jean - Gheerbrant, Alain, Slovar simbolov, Ljubljana, 2006.

Eberhard, Wolfram, A Dictionary of Chinese Symbols: Hidden Symbols in Chinese Life and Thought, London and New York, 1983.

Ilgo, Tina, Spremna beseda. Lu Xun: humanist, individualist in »bojevnik duha«, v: Lu, Xun: Dnevnik nekega norca in druge zgodbe, Ljubljana, 2008, 385-413.

Lavrač, Maja, Onkraj belih oblakov: Daoistična in budistična simbolika v poeziji kitajskega pesnika Wang Weija, Maribor, 1999.

Lee, Leo Ou-fan, Voices from the iron House, Bloomington \& Indianapolis, 1987.

Lin, Yutang, My Country and My People, Beijing, 2002.

Lu, Xun (Prev. Jana S. Rošker, Andrej Stopar, Katja Kolšek), Dnevnik nekega norca in druge zgodbe, Ljubljana, 2008.

Lu, Xun (Prev. Yang Xianyi, Gladys Yang), Selected Works II, Beijing, 2003.

Lu, Xun (Prev. Yang Xianyi, Gladys Yang), Selected Works IV, Beijing, 2003.

Lu, Xun (Prev. Bonnie S. McDougall), Letters between Two: Correspondence between Lu Xun and Xu Guangping, Beijing, 2000.

Lu, Xun, Lu Xun quanji yi (Lu Xunova zbrana dela I), Beijing, 1956.

Lu, Xun, Lu Xun quanji san (Lu Xunan zbrana dela III), Bijejing, 1956.

Lu, Xun (Prev. William A. Lyell), Diary of a Madman and other Stories, Honolulu, 1990.

Lyell, William A., »Introduction «, v: Diary of a Madman andOther Stories, Honolulu, 1990, xi-xlii.

Lyell, William A., Lu Hsun's Vision of Reality, Berkeley, 1976.

McDougall, Bonnie S. - Kam, Louie, The Literature of China in the Twentieth Century, New York, 1997.

Pollard, David E., The True Story of Lu Xun, Hong Kong, 2002.

Tambling, Jeremy, Madmen and Other Survivors: Reading Lu Xun's Fiction, Hong Kong, 2007.

Vuilleumier, Victor, The Writing of the Torn Body in Modern Chinese Literature, znanstveni prispevek, predstavljen na XVIII. bienalni mednarodni konferenci EACS (European Association of Chinese Studies), Riga, 2010 (dokumentirano na: http://www.eacs-riga2010.lv/sectione.html). 
Tina llgo

\section{Motifs of Madness, Indifference, and Cannibalism as Symbols of a Depraved Society in Lu Xun's Short Stories}

Keywords: Chinese literature, Lu Xun, motif of madness, motif of indifference, motif of cannibalism, »Diary of a Madman«, »The True Story of A Q«

This article analyzes two short stories by Lu Xun from his collection Outcry, which came into being at the culmination of the Chinese spiritual rebirth between 1818 and 1922. In "Diary of a Madman" and "The True Story of A Q" the author expresses his conviction that the existing system's depravity produces "cannibalism," causes a gradual decline in humanity, and exposes the main defects of human character. The impossibility of destroying the "iron house," or people's incapacity to change their "cannibalistic" nature, causes the loss of hope on the side of the "madmen" . It forces them to give up their insightfull knowledge and adapt to the majority. With the repetition of motifs such as "madness," "indifference," and "cannibalism," which constantly recur in Lu Xun's short stories, the author expressed his vision of traditional Chinese society and his pessimism about the future. At the same time these motifs reflect the author's state of mind and his everlasting journey between hope and despair, "madness" and "indifference," and tradition and modernity. If the stories are read in the context of twentieth-century China they can be understood as a direct criticism of the established Chinese society, whose values and norms derive from Confucianism, but they also contain deep symbolic meaning that renders them timeless. 